\title{
Gary S. Meltzer. Euripides and the Poetics of Nostalgia. Cambridge: Cambridge University Press, 2006.
}

Rene Georgopalis, University of Alberta

Meltzer, drawing upon deconstructionalist theories, argues that Euripides' tragedies exhibit a dialectic between tradition and rhetoric, the process of reasoning which he often labels as sophism, to establish authoritative knowledge. Meltzer uses the discussion of Polyneices and Eteocles in the Phoenician Women to illustrate this dialectic. Polyneices, who takes a traditional approach to authoritative knowledge, argues that "truth is single and plain" (2), and is based upon divine judgment, whereas Eteocles, who represents the school of thought based on reason and debate, views knowledge as contingent upon individual interpretation through reason and logic.

In Chapter One, Meltzer examines references to nostalgia in the Archaic Period, including the homecoming of Odysseus in the Odyssey, as well as Hesiod's hope for a return to the Golden Age. He then contends that in the Archaic Age authority to tell the truth and oversee justice was in the domain of the divine. In the fifth century $\mathrm{BCE}$, divine authority over justice and knowledge was challenged by some schools favoring reason and debate. Although divine authority was criticized by some schools of thought, many authors contemporaneous with Euripides, such as Aristophanes and Thucydides, exhibit an agon, or struggle, between traditional and non-traditional forms of authoritative knowledge with nostalgia for a simple and true traditional voice of the past. Criticisms of nontraditional forms of thought based on debate and rhetoric included the argument that immorality can be defended and that democracy

Past Imperfect

13 (2007) | ( ) | ISSN 1192-1315 
based on rhetoric produced an effeminate and cowardly society. Euripides, like his contemporaries, maintains this dialectic; he often uses female characters to exhibit the struggle between a "simple "word of truth", associated with Polyneices and "shifting, intricate interpretations" associated with Eteocles in Euripides' Phoenician Women (3). Meltzer opines that Euripides' female characters often search for a lost voice of truth but use sophistic thought and argument to advance their cause, a device which Meltzer labels “double speaking" (61).

From Chapters Two to Five, Meltzer analyzes Euripides' Hippolytus, Hecuba, Ion, and Helen according to the agon between traditional and rhetorical authority over knowledge and justice. In Chapter Two, Meltzer looks closely at the tension between traditional and non-traditional forms of knowledge as well as the references to nostalgia amongst the characters in the Hippolytus. Theseus unjustly curses his son Hippolytus to death when he incorrectly trusts the logic and rhetoric of Phaedra's suicide note rather than oracles and oaths. Likewise, Phaedra advocates archaic ideals of modesty and chastity, both of which were traditional ideals, yet she uses rhetoric, like a sophist, to preserve her reputation. Euripides also criticizes traditional authority in this play since even the gods, namely, Aphrodite and Artemis, exhibit self-interested interpretations of justice. Thus, Euripides' characters yearn for a simple truth, but any means to interpret justice, including the traditional one of divine authority, is self-serving.

In Chapter 3, Meltzer examines Euripides' portrayal of archaic ideals and rhetoric. Hecuba "double-speaks" as she uses rhetoric and appeals to the gods in attempt to save the life of her child, Polyxena. Polyxena uses the archaic language of nobility when faced with the reality of being sacrificed - in contrast, the heroes 
Odysseus, Agamemnon and Polymestor use rhetoric to justify sacrificing Polyxena. Meltzer opines that the use of such rhetorical devices by heroes in a heroic age is anachronistic. Additionally, the majority vote by the Greek heroes, who agree to sacrifice Polyxena, shows that the non-traditional means of determining the best course of action by consensus reveals to the Athenians their potential for brutality. Thus, Euripides outlines that debate as authority is dangerous because it can be used to defend tyranny.

In Chapter Four Meltzer posits that a struggle with divine authority over justice is exhibited in Ion. Apollo is portrayed as a possessor of both a "simple and true voice" and of "shifting, intricate interpretations." Apollo's actions are criticized as selfish and amoral when he rapes Creusa and abandons his child, and he is untruthful when he lies about Ion's paternity. Meltzer suggests that the criticism of the god reflects the criticisms of gods in Euripides' time. But at the end of the play, Athena's voice is presented as authoritative and just, since she confirms the mother-son relationship between Creusa and Ion. Ion depicts the divine voice as just although untruthful. Additionally, the play comments on the reliability of sense perception, as Creusa and Ion, unaware of their current reality, long for a lost mother-son relationship. Athena in the end clarifies the truth for the mother and son, and consequently, Meltzer argues that Euripides views the gods as a means for acknowledging truth and justice.

Helen is examined in Chapter Five. Once again, sense perception is questioned as the Trojan War is fought over a phantom image, since the real Helen was in Egypt and not in Troy. This phantom image blurs the word of truth of the heroic age. Meltzer argues that kleos, a word which the characters in Helen use to describe the Trojan War, is presented by Euripides with two 
meanings, heroic fame and rumor. Thus, heroic fame is juxtaposed with gossip which may be true or false. The entire purpose and heroic nature of the Trojan War is unfounded by the fact that Helen was actually in Egypt the entire time. The nostalgia of the play lies in the restoration of the lost grandeur of the Trojan War. Meltzer contends that Euripides is concerned with the existence of heroic elements of war since this play was written after Athens' destruction in the Sicilian War (413 BCE).

Meltzer's work is significant because he draws upon the role of nostalgia in Euripides' four plays, with consideration of the historical context within which Euripides wrote. Additionally, while taking into account the importance of Euripides' portrayal of gender, Meltzer analyzes the agon between the traditionalist, who longs for a definite and truthful form of justice and the "sophist," who uses reason and logic as an authority of justice. However, some of Meltzer's parallels with our contemporary world and Euripides' world at times are extended too far or are unnecessary for understanding Euripides' texts. For instance, it is anachronistic to compare multiple epistemologies of $21^{\text {st }}$ century postmodernism to the criticism of divine authority and perceived authority as contingent upon personal interpretation of the Greek world. Nonetheless, Meltzer's work provides an important analysis of the manner in which nostalgia is depicted in Euripides' Hippolytus, Hecuba, Ion and Helen since he provides insight into the thought in Euripides' time regarding traditional and untraditional authority. 